\title{
REFORMASI PENDIDIKAN ISLAM DI INDONESIA
}

\author{
Muh. Idris \\ Sekolah Tinggi Agama Islam Negeri Manado
}

\begin{abstract}
A bstract Education reform aims to be effective and efficient in achieving national education goals. In Laws and Regulations seen the desire of the Indonesian government to empower the people of Indonesia through the provision of superior education. The government clearly has put content standards, processes, competence of graduates, educators and education personnel, facilities and infrastructure, management, finance, and educational assessment. Over a period of more than five decades since Indonesia is free from colonialism, Islamic education can be said to have not been able to contribute anything to the progress of the nation, in addition to not being able to complain when required role in addressing the problems of this nation's morals and mentality. Islamic education and Islamic boarding school either unwittingly still stuck on dichotomous orientation. The indication, the Islamic educational institutions is the transformation of knowledge and religious values was so strong that it is almost forgotten reality of the labor market.
\end{abstract}

Keywords: reform, Islamic education, Indonesia

\begin{abstract}
A bstrak: Reformasi pendidikan bertujuan agar pendidikan dapat berjalan dengan efektif dan efisien dalam mencapai tujuan pendidikan nasional. Dalam Undang-undang dan Peraturan terlihat adanya keinginan dari pemerintah Indonesia untuk memberdayakan rakyat Indonesia melalui pemberian pendidikan yang unggul. Pemerintah dengan jelas telah meletakkan standar isi, proses, kompetensi lulusan, pendidik dan tenaga kependidikan, sarana dan prasarana, pengelolaan, pembiayaan, dan penilaian pendidikan. Selama kurun waktu lebih dari lima dasawarsa sejak Indonesia bebas dari kolonialisme, pendidikan Islam bisa dikatakan belum bisa memberikan kontribusi apa-apa terhadap kemajuan bangsa, di samping tidak mampu berkutik ketika dituntut perannya dalam mengatasi berbagai persoalan moral dan mentalitas bangsa ini. Pendidikan Islam baik pesantren maupun madrasah tanpa disadari masih terjebak pada orientasi dikotomik. Indikasinya, dalam lembaga-lembaga pendidikan Islam tersebut transformasi pengetahuan dan nilai-nilai agama terasa begitu kuat sehingga hampirhampir melupakan realitas kebutuhan pasar kerja.
\end{abstract}

Kata K unci: reformasi, pendidikan Islam, Indonesia

\section{PENDAHULUAN}

Pendidikan ${ }^{1}$

merupakan kebutuhan

penting bagi manusia, negara, maupun pemerintah. Karena pendidikan yang menentukan corak baik danjeleknyaperjalanan sejarah hidup manusia. Karena itu, harus sel alu ditumbuhkembangkan secara sistematis oleh para pengambil kebijakan. Pembaruan- pembaruan harus selalu diupayakan agar pendidikan benar-benar dapat memberikan kontribusi yang signifikan dalam usaha untuk mencerdaskan kehidupan bangsa.

Sudah menjadi kenyataan bahwa dunia pendidikan adalah dunia yang penuh kritik. Diakui oleh Mastuhu sebagaimana yang dikutip oleh Suwito bahwa debat akademik 
mengenai masalah pendidikan tidak pernah selesai dan tidak terelakkan. Menurutnya, hal ini disebabkan karena salah satu keunikan dalam kehidupan manusia tidak pernah sepi dari nilai-nilai luhur yang dicitacitakan. Sementara itu, manusia memang mampu membuat berbagai pertanyaan dan menciptakan berbagai jalan yang semakin lama semakin maju dan canggih. A kan tetapi ia juga mengakui bahwa manusia belum pernah memperoleh jawaban final yang memuaskan hidupnya. Manusia selalu berada dalam proses terus-menerus mencari jawaban. ${ }^{2}$

Sistem pendidikan nasional yang telah dibangun selama tiga dasawarsa terakhir ini ternyata belum mampu sepenuhnya menjawab kebutuhan dan tantangan nasional dan global dewasa ini. Program pemerataan dan peningkatan kualitas pendidikan yang selama ini merupakan fokus pembinaan masih menjadi masalah yang paling menonjol dalam dunia pendidikan kita. Jumlah angka penduduk usia pendidikan dasar yang berada di luar sistem pendidikan nasional masih menunjukkan angka yang sangat besar, sementara itu kualitas pendidikan masih jauh dari yang diharapkan.

Padasisilain,tantangandanperkembangan lingkungan strategis, baik nasional maupun internasional dalam berbagai bidang kehidupan semakin berat. Perkembangan ilmu pengetahuan dan teknologi, khususnya dibidang informasi, komunikasi dan transportasi yang amat cepat, eskalasi pasar bebas antar negara dan bangsa yang semakin meningkat, iklim kompetisi dalam berbagai bidang kehidupan yang semakin ketat, dan tuntutan demokratisasi serta masalah hak azazi manusia merupakan tantangan yang harus dijawab oleh bangsa Indonesia agar agar kita bisa hidup terus dan bertahan dalam percaturan kehidupan antar bangsa di dunia. ${ }^{3}$

Ditingkat lokal tuntutan masyarakat terhadap penyelenggaraan kehidupan

bermasyarakat, berbangsa dan bernegara yang lebih adil, terbuka, dan demokratis semakin santer dibicarakan oleh anggota masyarakat. Paradigma sistem pendidikan Nasional yang selama ini menjadi acuan penyelenggaraan pendidikan di Indonesia perlu dikaji dan disempurnakan. Bangunan pendidikan

selama ini perpedoman pada konsepsi inputoutput analysis. Paradigma yang mempunyai akar teori pada bidang ekonomi produksi ini berkeyakinan bahwa apabila input diperbaiki, maka secara otomatis output akan menjadi baik pula. Ini dikarenakan lembaga pendidikan tidak bisa disamakan dengan pabrik dalam dunia industri sebab input pendidikan bukan input yang statis melainkan input dinamis yang banyak dipengaruhi oleh berbagai faktor khususnya faktor proses dan konteks pendidikan.

Karena itu paradigma sistem pendidikan harus mencakup kedua faktor di atas (proses dan konteks) di samping faktor input dan output pendidikan. Bahkan dalam hal pendidikan faktor input justru tidak terlalu dipermasalahkan. Faktor-faktor proses

dan konteks yang menentukan output pendidikan. Karena itu masalah-masalah semacam kurikulum, kualitas guru, metode pengajaran yang efektif dan menyenangkan serta manajemennya menjadi sangat penting dalam proses pendidikan di sekolah. Sistem pendidikan yang baik adalah justru bila seorang anak didik yang kurang memiliki kecerdasan dan kemampuan berketerampilan setelah diproses dalamsistem tersebut menjadi meningkat dan mampu mengembangkan keterampilannya. $^{4}$ 


\section{Pendidikan Islam}

Hampir di setiap diskusi selalu saja timbul pertanyaan, mengapa terjadi begitu senjang dan terpisah antara satu sisi ajaran agama yang diyakini benar, hebat dan tinggi, dan di sisi lain realitas perilaku para pemeluknya yang sama sekali berbeda dengan ajaran agamanya? Dalam ajaran Islam ada sebuah pernyataan yang biasanya diyakini oleh kaum Muslimin sebagai hadis $\mathrm{N}$ abi yaitu penegasan bahwa "Islam itu sangat tinggi dan karenanya tidak ada yang lebih tinggi darinya." Pernyataan ini yang sering didengung-dengungkan untuk menegaskan bahwa I slam itu hebat dan tinggi sehingga bila terjadi penyelewengan dan kezaliman yang dipersalahkan adalah para penganutnya, karena dianggap tidak memahami sekaligus tidak mempraktekkan ajaran agamanya secara benar. ${ }^{5}$

Sekilas memang argument tersebut dapat diterima. Tapi bila dikritisi, maka akan timbul pernyataan: jika ajaran Islam itu memang benar, hebat, dan tinggi, tapi ternyata tidak mampu memengaruhi para pemeluknya, Ialu dimana pembuktian kebenaran, kehebatan dan ketinggian ajarannya itu? Dan apa gunanya ajaran Islam yang benar, hebat dan tinggi itu tapi tidak mampu memengaruhi perilaku pemeluknya?

Inilah kira-kira problem umat Islam saat ini. Dan tampaknya problem tersebut diakibatkan oleh adanya orientasi pendidikan agama yang kurang tepat. Tiga hal yang bisa dikemukakan untuk membuktikan kekurangtepatan orientasi pendidikan yang dimaksud adalah: pertama, pendidikan agama saat ini lebih berorientasi pada belajar tentang agama, karena itu tidak aneh kalau sering kita saksikan seseorang yang mengetahui nilainilai ajaran agama, tetapi perilakunya tidak relevan dengan nilai-nilai ajaran agama yang diketahuinya.

$K e d u a$, tidak tertibnya penyusunan dan pemilihan materi-materi pendidikan agama sehingga sering ditemukan hal-hal yang prinsipil yang seharusnya dipelajari lebih awal, malah terlewatkan. Kekacauan materi pendidikan agama ini terlebih jelas lagi terlihat pada pemilihan disiplin ilmu figh yang dianggapnya sebagai agama itu sendiri. Disebabkan oleh orientasi pendidikan agama semacamitu, kitasering menyaksikan penilaian masyarakat yang menurut mereka, bahwa beragama yang benar adalah bermazhab figh yang benar dan yang diakui oleh mayoritas. Sedikit saja berbeda dengan mazhab yang dianut mayoritas, maka diklaimlah sebagai sesat dan menyimpang.

Ketiga, kurangnya penjelasan yang luas dan mendalam serta kurangnya penguasaan semantic dan generic atas istilah-istilah kunci dan pokok dalam ajaran agama sehingga sering ditemukan penjelasan yang sudah sangat jauh dan berbeda dari makna, sprit, dan konteksnya. Pada gilirannya kondisi semacam ini menjadikan ajaran-ajaran agama yang dipegang dan dianggap benar oleh para pemeluknya adalah ajaran agama yang sudah menyejarah ratusan tahun. Sehingga seringkali tidak diketahui dari mana sumbernya, apakah dari al-Qur'an, sunnah, atau dari pengalaman panjang kaum muslimin yang setiap periode tertentu membentuk dan mengkristalkan kepentingannya sehingga lama kelamaan kepentingan yang kontekstual itu dianggap sebagai peraturan Islam dan diklaim sebagai bagian integral dari ajaran Islam. Akibat pendidikan agama semacam ini, kaum muslim biasanya lebih merasa benar berpegang pada produk-produk pemikiran konvensional yang tidak begitu jelas dari mana berasal dari 
pada berpegang langsung pada al-Qur'an dan sunnah. ${ }^{6}$

Tampaknya orientasi pendidikan agama semacam itulah yang menyebabkan kenapa terjadi keterpisahan dan kesenjangan antara satu sisi ajaran agama dan di sisi lain realitas perilaku para pemeluknya. Karenaitu orientasi pendidikan agama yang selama ini perlu ditinjau-ulang secara kritis untuk menemukan orientasi pendidikan agama yang lebih tepat dan berdaya guna. ${ }^{7}$

Zarkowi Soejoeti dalam makalahnya tentang "Model-model Perguruan Tinggi Islam" sebagaimana yang dikutip oleh A. Malik Fadjar mengemukakan bahwa pendidikan Islam paling tidak mempunyai tiga pengertian. Pertama, lembaga pendidikan Islam itu pendirian dan penyelenggaraannya didorong oleh hasrat mengejawantahkan nilai-nilai Islam yang tercermin dalam nama lembaga pendidikan itu dan kegiatan-kegiatan yang diselenggarakan. Dalam pengertian ini, Islam dilihat sebagai sumber nilai yang harus diwujudkan dalam kehidupan lembaga pendidikanyangbersangkutan.Kedua, lembaga pendidikan yang memberikan perhatian dan menyelenggarakan kajian tentang Islam yang tercermin dalam program kajian sebagai ilmu dan diperlakukan sebagai ilmu-ilmu lain yang menjadi program kajian lembaga pendidikan Islamyang bersangkutan. Ketiga, mengandung dua pengertian di atas dalam arti lembaga tersebut memperlakukan Islam sebagai sumber nilai bagi sikap dan tingkah laku yang harus tercermin dalam penyelenggaraannya maupun sebagai bidang kajian yang tercermin dalam program kajiannya. ${ }^{8}$

Konsep pendidikan Islam sebagaimana dikemukakan oleh Zarkowi Soejoeti tersebut, walaupun belumcukup memadai secara fal safi untuk disebut sebagai pendidikan Islam, tetapi dapat dijadikan sebagai pengantar dalam memahami pendidikan Islam secara lebih mendasar. ${ }^{9}$

Pendidikan dapat diartikan sebagai bimbingan atau pembinaan terhadap peserta didik. Pendidikan dapat diartikan secara sempit dan dapat pula diartikan secara luas. Secara sempit dapat diartikan sebagai bimbingan yang diberikan kepada anak-anak sampai ia dewasa. ${ }^{10}$. Pendidikan juga dapat diartikan secara luas yaitu segal a sesuatu yang menyangkut proses perkembangan manusia, yaituupayamenanankandanmengembangkan nilai-nilai bagi peserta didik, sehingga nilainilai yang terkandung dalam pendidikan itu menjadi bagian dari kepribadian peserta didik, yang pada gilirannya ia menjadi orang pandai, baik, mampu hidup dan berguna bagi masyarakat. ${ }^{11}$

Definisi di atas mengandung pengertian yang lebih luas, yakni menyangkut perkembangan dan pengembangan manusia. Namun demikian pengertian ini masi terbatas dalam persoalan-persoalan duniawi yang belum memasukkan aspek spiritual religius sebagai bagian terpenting yang mendasari perkembangan dan pengembangan manusia dalam proses pendidikan.

Pendidikan Islam sangat berperan untuk senantiasa diaktualisasikan sehingga bisa menjadi petunjuk sesuai dengan fungsinya antara lain sebagai faktor pembimbing, pembina, pengimbang, penyaring dan pemberi arah dalam hidup menuju masyarakat yang di dal amnya tecipta persemakmuran intelektual di dalam bingkai agama. Tidak ada obat yang dapat menyembuhkan kecuali syari'at Islam itu sendiri yang di dalamnya sarat dengan petunjuk kearah kebaikan. ${ }^{12}$ Pendidikan Islam 
merupakan pangkal ketaatan dan kebenaran, merupakan sarana untuk menciptakan manusia menjadi mukmin yang sempurna ${ }^{13}$ serta menjadikan manusia sebagai hamba Allah yang shaleh dalam seluruh segi kehidupannya. ${ }^{14}$ Pendidikan Islam yang tujuan akhirnya mengarahkan agar anak didik menjadi manusia yang bertaqwa kepada Allah ${ }^{15}$.

Syed Naquib al Attas dalam hal ini menyatakan bahwa pendidikan berasal dari kata $t a^{\prime}$ diib. Memang terdapat kata lain selain ta'diib yaitu tarbiyah, akan tetapi tarbiyah lebih menekankan kepada mengasuh, menanggung, memberi makan, memelihara, dan menjadikan bertambah dalam pertumbuhan. ${ }^{16}$ Selanjutnya, Nuqaib menyatakan bahwa penekanan pada "adab" yang mencakup amal dalam pendidikan dan proses pendidikan adalah untuk menjamin bahwasanya ilmu dipergunakan secara baik dalam masyarakat. Karena alasan inilah orang-orang bijak terdahulu mengkombinasikan ilmu dengan amal dan adab, dan menganggap kombinasi harmonis ketiganya sebagai pendidikan. ${ }^{17}$

Pendidikan memang bukan sekedar transfer pengetahuan, pembinaan mental jasmani dan intelek semata, tetapi bagaimana pengetahuan dan pengalaman yang telah didapatkan dipraktekkan dalam prilaku sehari-hari. Ki Hajar Dewantara dalam hal ini menyatakan bahwa pendidikan adalah usaha yang dilakukan dengan penuh keinsyafan yang ditujukan untuk keselamatan dan kebahagiaan manusia. Pendidikan tidak hanya bersifat pelaku pembangunan tetapi sering merupakan perjuangan pula. Pendidikan berarti memelihara hidup tumbuh ke arah kemajuan, tidak boleh melanjutkan keadaan kemarin. Pendidikan adalah usaha kebudayaan, berazas peradaban, yakni memajukan hidup agar mempertinggi derajat kemanusiaan. ${ }^{18}$

Rumusan pendidikan di atas, tampak memberikan kesan dinamis, modern, dan progresif. Pendidikan tidak boleh hanya memberikan bekal untuk membangun, tetapi seberapa jauh didikan yang diberikan itu dapat berguna untuk menunjang kemajuan suatu bangsa. Semangat progresif yang terkandung dalam pendidikan sebagaimana definisi di atas, tampak mengingatkan kita pada pesan Khalifah Umar yang mengatakan bahwa anak-anak muda masa sekarang adalah generasi di masa yang akan datang. Dunia dan kehidupan yang akan dihadapi berbeda dengan dunia yang sekarang, untuk itu apa yang akan diberikan pada anak didik harus memperlihatkan kemungkinan relevansi dan kegunaannya di masa datang. ${ }^{19}$

Menurut H.M Arifin, dengan mengutip rumusan dari hasil seminar Pendidikan Islam se-Indonesia di Cipayung Bogor tanggal 1711 Mej 1960, menyatakan bahwa pendidikan Islam adalah sebagai bimbingan terhadap pertumbuhan rohani dan jasmani menurut ajaran Islam dengan hikmah mengarahkan, mengajarkan, melatih, mengasuh, dan mengawasi berlakunya semua ajaran Islam. Islam membimbing, mengarahkan dan mengasuh serta mengajarkan atau melatih, mengandung pengertian usaha memengaruhi jiwa anak didik melalui proses setingkat demi setingkat menuju tujuan yang ditetapkan, yaitu menamkan takwa dan akhlak serta menegakkan kebenaran sehingga terbentuklah manusia yang berpribadi dan berbudi luhur sesuai ajaran Islam. ${ }^{20}$

Setidak-tidaknya ada tiga poin yang dapat disimpulkan dari definisi pendidikan di atas, yaitu 1). Pendidikan Islam menyangkut aspek 
jasmani dan rohani. Keduanya merupakan satu kesatuan yang tidak dapat dipisahkan. Oleh karena itu, pembinaan terhadap keduanya harus serasi, selaras, dan seimbang. 2). Pendidikan Islam mendasarkan konsepnya pada nilai-nilai relegius. Ini berarti bahwa pendidikan Islam tidak mengabaikan faktor teologis sebagai sumber dari ilmu itu sendiri, sebagaimana QS al-Baqarah:31: "Dan Dia mengajarkan kepada Adam nama-nama (bendabenda) seluruhnya, kemudian mengemukakannya kepada para malaikat, lalu berfirman: Sebutkanlah kepada-Ku nama-nama benda itu jika kamu memang orang-orang yang benar.

Ayatinimenunjukkanadanyaepistemologi dalam Islam, yaitu bahwa ilmu pengetahuan bersumber dari Allah. Dialah pendidik yang pertama dan utama. Bedanya dengan orang tua sebagai pendidik yang pertama dan utama adalah bahwa orang tua merupakan pendidik pertama dan utama bagi anak-anaknya dalam keluarga. Allah adalah pendidik pertama dan utama bagi seluruh makhluk manusia, bahkan seluruh alam. Tidak ada satu pendidikan yang terjadi dalam keluarga, bahkan dalam alam jagat raya ini, tanpa Allah sebagai pendidik pertama dan utama yang mengajarkan ilmunya kepada manusia dalam hal ini Adam sebagai manusia pertama. 3). Adanya unsur takwa sebagai tujuan yang harus dicapai. Sebagaimana yang kita ketahui bahwa takwa merupakan benteng yang dapat berfungsi sebagai daya tangkal terhadap pengaruhpengaruh negatif yang datang dari luar.

Berdasarkan pengertian-pengertian di atas dapat disimpulkan bahwa pendidikan Islam adalah bimbingan yang diberikan oleh seseorang kepada seseorang agar ia berkembang secara maksimal sesuai dengan ajaran Islam.

\section{Reformasi Pendidikan Islam di Indonesia}

Reformasi pendidikan ${ }^{21}$ menuntut adanya cara berpikir dan bertindak yang berbeda dari apa yang telah ada dengan mengadakan diagnosis secara menyeluruh atau perubahan paradigma dengan pendekatan yang sistemik. Paradigma yang sistemik kecuali bersifat menyeluruh, harus pula memperhatikan bahwa perubahan mendasar pada salah satu aspek pendidikan, akan memengaruhi perubahan mendasar pada aspek-aspek lain. Perubahan itu dapat dibedakan pada empat lapis sistem yang saling berkaitan. Pada lapis pertama adalah perubahan pada pengalaman belajar, lapis kedua pada sistem belajar-pembelajaran yang menungkankan terlaksananya pengalaman belajar yang diinginkan, seperi misalnya dalam sekolah. Lapis ketiga adalah perubahan pada pengalaman sistem pembelajaran, dan lapis keempat adalah perubahan pada sistem perundangan yang mengatur dan menjamin berlangsungnya keseluruhan sistem pendidikan secara nasional. ${ }^{22}$

Berdasarkan hakekat reformasi sebagai pemberdayaan warga, maka sudah seharusnya perhatian utama diberikan pada perubahan pada lapis pertama, yaitu pengalaman belajar, dengan konsekwensi dan implikasi pada perubahan pada lapis kedua sampai keempat. Pendekatan mulai lapis pertama disebut pula sebagai pendekatan dari bawah ke atas (bottom-up approach). Selama ini apa yang terjadi adalah pendekatan dari atas ke bawah (top-down approach), di mana pemerintah pusat menentukan perundangan dan serangkaian peraturan pelaksanaan yang harus dipatuhi oleh jajaran di bawah sampai di ruang kelas atau lingkungan belajar tempat peserta didik atau warga belajar memperoleh 
dan mengembangkan pengalaman belajarnya. ${ }^{23}$

Dengan pendekatan dari bawah ke atas maka perhatian utama diberikan kepada peserta didik agar mereka menguasai tugas belajar dan mapu mengatasi persoalan belajar. Semua satuan penyelenggara pendidikan, termasuk sekolah, pusat kegiatan belajar masyarakat, perguruan tinggi, dan sebagainya, wajib mengel ola sumber dayayang diperlukan dan mengatur penggunaannya. Pada gambar di bawah ini dapat dilihat pendekatan paradigma lama dan reformatif. bangsa sebagaimana yang tertuang dalam pembukaan Undang-undang Dasar 1945 ini mengisyaratkan tentang pentingnya memberikan pendidikan yang unggul dan merata bagi seluruh rakyat Indonesia sebagai modal untuk meraih kemajuan dalam berbagai bidang kehidupan lainnya. ${ }^{25}$

Kehidupan pada millenium ketiga benarbenar berada pada tingkat persaingan global yang sangat ketat. Artinya siapa saja yang tidak memenuhi syarat kualitas global, akan tersingkir secara alami dengan sendirinya. Pertanyaannya sudahkah kita siap akan hal

Tabel 1. Perbandingan Antar Paradigma "Top-down" dan Bottom-up"

\begin{tabular}{|c|c|c|}
\hline \multirow[b]{2}{*}{ LAPIS } & \multicolumn{2}{|c|}{ PENDEKATAN } \\
\hline & $\begin{array}{c}\text { Paradigma lama (Top-Down } \\
\text { Approach) }\end{array}$ & $\begin{array}{c}\text { Paradigma Reformasi (Bottom-Up } \\
\text { Approach) }\end{array}$ \\
\hline $\begin{array}{l}\text { Nasional (Sistem } \\
\text { Pendidikan) }\end{array}$ & $\begin{array}{l}\text { Menetapkan ketentuan perundangan, } \\
\text { antara lain untuk membudayakan } \\
\text { peserta didik }\end{array}$ & $\begin{array}{l}\text { Menjamin tersedianya aturan pokok dan } \\
\text { sumber yang diperlukan }\end{array}$ \\
\hline $\begin{array}{l}\text { Wilayah (Sistem } \\
\text { Pengelolaan) Provinsi, } \\
\text { Kabupaten, \& Kodya }\end{array}$ & $\begin{array}{l}\text { Menerbitkan Peraturan dan Petunjuk } \\
\text { Operasional dari perundangan yang } \\
\text { ada }\end{array}$ & $\begin{array}{l}\text { Menyediakan informasi dan bantuan, } \\
\text { menjabarkan aturan serta membagi dan } \\
\text { mengawasi sumber daya yang diperlukan }\end{array}$ \\
\hline $\begin{array}{l}\text { Sekolah (Sistem Belajar- } \\
\text { Pembelajaran }\end{array}$ & $\begin{array}{l}\text { Melaksanakan petunjuk dan } \\
\text { mengawasi kegiatan }\end{array}$ & $\begin{array}{l}\text { Merancang pedoman pelaksanaan } \\
\text { serta mengelola sumber daya dan } \\
\text { penggunaannya }\end{array}$ \\
\hline Pengalaman Belajar & $\begin{array}{l}\text { Peserta didik merespons pelajaran } \\
\text { yang diberikan }\end{array}$ & $\begin{array}{l}\text { Peserta didik menguasai tugas belajar serta } \\
\text { mampu memecahkan masalah belajar }\end{array}$ \\
\hline
\end{tabular}

Perubahan paradigmaini (dari etatismeke pemberdayaan peserta didik) memengaruhi semua aspek pendidikan lain, bahkan memicu tumbuhnya serangkaian paradigma lain. Perubahan paradigma ini memunculkan konsep-konsep baru seperti belajar berbasis aneka sumber pengelolaan berbasis sekolah dan pola pembelajaran atau pendekatan alternatif. ${ }^{24}$
Kesadaran untuk memajukan dunia pendidikan di Indonesia sesungguhnya telah tertanam kuat dalam jiwa para pendiri negara republik tercinta ini. Di antara isi Pembukaan Undang-Undang Dasar 1945 dengan tegas menyatakan bahwa salah satu tujuan pembentukan pemerintahan negara Indonesia ini adalah untuk mencerdaskan kehidupan bangsa. Cita-cita mencerdaskan kehidupan 
itu? kelihatannya belum. Itulah sebabnya kita perlu selalu melakukan pembaruan dalam bidang pendidikan dari waktu ke waktu tanpa henti sekaligus menjadi juru bicara, baik skala nasional maupun internasional. Kita tidak boleh lagi selalu membanggakan keberhasilan masa lalu tanpa mengkaji ulang relevansi keberhasilan itu dengan setting kehidupan global masa kini dan akan datang. Untuk itu kita patut memperhatikan metafora John F. Kennedy yaitu; "Change is a way of life. Those who look to the past or present will miss the future". Metafora ini pantas kita terjemahkan dalam kepentingan reformasi pendidikan. Artinya dalam melakukan reformasi pendidikan kita harus tetap berpegang pada tantangan masa depan yang penuh dengan persaingan gl obal. ${ }^{26}$

Reformasi pendidikan pada dasarnya memiliki tujuan agar pendidikan dapat berjalan lebih efektif dan efesien mencapai tujuan pendidikan nasional ${ }^{27}$. Untuk itu dalam reformasi terdapat dua hal yang perlu dilakukan:

1. Mengidentifikasi berbagai problem yang menghambat terlaksananya pendidikan

2. Merumuskan reformasi yang bersifat strategik dan praktis sehingga dapat diimplementasikan di lapangan.

Oleh karena itu kondisi yang diperlukan dan program aksi yang harus diciptakan merupakan titik sentral yang harus diperhatikan dalam setiap reformasi pendidikan. Dengan kata lain reformasi pendidikan harus mendasarkan pada realitas sekolah yang ada bukan mendasarkan pada etalase atau jargon-jargon pendidikan semata. Reformasi hendaknya didasarkan fakta dan hasil penelitian yang memadai dan valid, sehingga dapat dikembangkan program reformasi yang utuh, jelas dan realistis. ${ }^{28}$
Untuk menciptakan keunggulan kompetitif, bangsa Indonesia memerlukan inovasi yang pesat dalam dunia pendidikan. Menjadi bangsa yang berharkat memerlukan keunggulan yang kompetitif dalam berbagai bidang. Bukan zamannya lagi apabila kita mengandalkan murahnya tenaga kerja untuk mendukung dan membenarkan konsep keunggulankomparatifdankompetitif ${ }^{29}$.Dalam konteks untuk menciptakan keunggulan yang kompetitif sebagai outcame suatu pendidikan patut kiranya kita mengkaji pendapat Michael Porter yang mengungkapkan bahwa: the ability to sustain an advantage from cheap labor or even from economies of scale-these arethe old paradigms. These paradigms are being supertseded. Today, the only way to have an advantage is through innovation an upgrading. ${ }^{30}$

Dari pendapat Porter di atas, jika bangsa Indonesia ingin menghasilkan berbagai keunggulan kompetitif dari outcame pendidikan, inovasi harus menjadi prioritas penting dalam pengembangan sistem pendidikan. Tanpaadainovasi yangsignifikan, pendidikan nasional hanyaakan menghasilkan lulusan yang tidak mandiri, selalu tergantung pda pihak lain. Dalam perspektif global, hasil pendidikan yang demikian itu justru akan menjadi beban bagi bangsa dan negara, sekaligus bagi masyarakat. ${ }^{31}$

Berbagai kebijakan dalam bidang pendidikan yang ditempuh oleh pemerintahan orde baru seperti melalui SKB 3 Mentri tahun 1976, pengangkatan guru melalui melalui program UGA (Ujian Guru Agama), serta Undang-undang No.2 Tahun 1989 tentang Sistem Pendidikan Nasional ternyata masih menggambarkan sikap yang setengah

hati dan belum sungguh-sungguh untuk memberdayakan rakyat Indonesia melalui dunia pendidikan. Hasil Komisi Penelitian 
Tim Reformasi Pendidikan yang diketuai Prof. Dr. Soeyanto dari Universitas Negeri Yogyakarta misalnya menyebutkan bahwa pendidikan yang dilaksanakan pada zaman orde baru belum mampu menghasilkan pendidikan yang unggul dan memberdayakan peserta didik. Pemerintah orde baru juga belum dapat memberikan pendidikan yang merata bagi seluruh rakyat Indonesia, serta belum mampu menghasilkan lulusan yang memiliki wawasan pengetahuan yang luas, keterampilan serta akhlak yang mulia. Berdasarkan kenyataan ini, Tim Reformasi pendidikan ini mengusulkan agar UndangUndang No. 2 Tahun 1989 tentang Sistem Pendidikan Nasional itu segera diperbaharui dengan Sistem Pendidikan Nasional yang memenuhi harapan dan tuntutan era global yang kompetitif. ${ }^{32}$

Kini harapan untuk memperoleh pendidikan yang unggul dan memberdayakan serta merata bagi seluruh rakyat Indonesia mulai terbuka. Harapan ini tercermin dalam sejumlah kebijakan strategis yang ditempuh oleh Pemerintah Kabinet Indonesia Bersatu dengan lahirnya Undang-Undang No. 20 Tahun 2003 Tentang Sistem Pendidikan Nasional, naiknya anggaran pendidikan yang mencapai $20 \%$ dari APBN, Undang-Undang N o. 14 Tahun 2005 Tentang Standar Nasional Pendidikan, Peraturan Mentri Pendidikan Nasional RI N o. 2Tahun 2005 Tentang Subsidi Silang Biaya Operasional Perguruan Tinggi, serta Peraturan Mentri Pendidikan Nasional N o. 8Tahun2005Tentang TataKerjaDirektorat Jendral Peningkatan Mutu Pendidik dan tenaga Kependidikan Depertemen Pendidikan Nasional.

Di dalam berbagai Undang-undang dan Peraturan tersebutterlihat dengan jel asadanya kemauan politik yang kuat dari pemerintah
Indonesia untuk memberdayakan rakyat Indonesia melalui pemberian pendidikan yang unggul dan memberdayakan dengan meninjau kembali seluruh komponen yang terkait dengan pendidikan. Pemerintah dengan jelas telah meletakkan standar isi, proses, kompetensi lulusan, pendidik dan tenaga kependidikan, sarana dan prasarana, pengelolaan, pembiyaan, dan penilaian pendidikan. $^{33}$

Menurut Azyumardi Azra perumusan konsep tentang reformasi pendidikan, arah baru pendidikan nasional--yang bisa disebut merupakan salah satu fungsi pokok dan tujuan akhir pendidikan--adalah mempersiapkan individu anak didik dan warga masyarakat yang memiliki kemampuan untuk mengaktualisasikan, melembagakan dan mengembangkan masyarakat madani Indonesia, yang akan dibahas lebih rind di bawah.

Untuk mencapai tujuan tersebut, kebijaksanaan pendidikan nasional jangka panjang seharusnya bertumpu pada usahausaha: pertama, menjamin kesempatan (equity) bagi setiap anak bangsa untuk memperoleh pendidikan yang selaras dengan kebutuhan masyarakat lingkungan masing-masing, dan pada saatyang samajugamemberikan peluang yang luas bagi peningkatan kemampuan pendidikan masyarakat dengan memberikan kesempatan bagi diversifikasi program pendidikan; kedua, menyelenggarakan

pendidikan yang relevan dan bermutu sesuai dengan kebutuhan masyarakat madani Indonesia dalam menghadapi tantangan global, dan padasaatyang sama meningkatkan efisiensi internal dan eksternal pada semua jalur, jenjang dan jenis pendidikan; ketiga, menyelenggarakan sistem pendidikan yang demokratis dan profesional, dan dapat 
dipertanggungjawabkan (accountable) bagi masyarakat dan seluruh stakeholderslainnya; keempat, mengurangi peranan pemerintah, sehingga lebih merupakan fasilitator dalam implementasi sistem pendidikan, dan pada saat yang sama merampingkan birokrasi pendidikan agar lebih fleksibel dalam meresponi perubahan dan dinamika perkembangan masyarakat baik di tingkat nasional maupun global.

Berdasarkan kerangka arah dan kebijakan pendidikan nasional jangka panjang itu, selanjutnya dapat dirumuskan arah, kebijakan dan strategi pendidikan nasional, baik untuk jangka menengah dan jangka pendek. Rincian-rincian dari semua arah, kebijakan, dan strategi pendidikan tersebut agaknya tidak perlu dikemukakan di sini. Yang penting ditekankan adalah bahwa sistem dan proses pendidikan nasional, sekali lagi, mestilah memberikan penekanan sangat kuat bagi penyiapan anak bangsa agar memiliki kemampuan, kecakapan dan motivasi dalam aktualisasi dan institusionalisasi masyarakat madani Indonesia. Di sini juga jelas, bahwa "nation and character building" harus menjadi inti dan salah satu tujuan pokok pendidikan nasional. ${ }^{34}$

Sebagaimana diketahui umum, selama kurun waktu lebih dari lima dasawarsa sejak Indonesia bebas dari kolonialisme, pendidikan Islam bisa dikatakan belum bisa memberikan kontribusi apa-apa terhadap kemajuan bangsa, di samping tidak mampu berkutik ketika dituntut perannya dalam mengatasi berbagai persoalan moral dan mentalitas bangsa ini. Pendidikan Islam baik pesantren maupun madrasah tanpa disadari masih terjebak pada orientasi dikotomik. Indikasinya, dalam lembaga-lembaga pendidikan Islam tersebut transformasi pengetahuan dan nilai-nilai agama terasa begitu kuat sehingga hampirhampir melupakan realitas kebutuhan pasar kerja. ${ }^{35}$

Pendidikan Islam masih dihadapkan pada persoalan dualisme-dikotomi antara ilmuilmu agama dan ilmu-ilmu umum. Selain itu, pendidikan Islam, dinilai masih belum menuntaskan konsep-konsep normatif yang berhubungan dengan cita ideal manusia yang dihasilkan. ${ }^{36}$ Menurut I qbal bahwa ada tiga hal yang menyebabkan kemunduran Pendidikan umat Islam yaitu: Pertama mistisisme asketik. ${ }^{37} \mathrm{Kedua}$, hilangnya semangat induktif. Ketiga, adanya ideal isasi capaian-capaian masa lampau, absolutisme pemikir mazhab dan otoritas perundang-undangan yang mapan, telah melumpuhkan perkembangan pribadi dan menyebabkan hukum Islam praktis tidak bisa bergerak sama sekali. ${ }^{38}$ Oleh karena itu diperlukan reformasi dalam pendidikan Islam.

PadaerakolonialisBelanda,perkembangan madrasah dimulai dari semangat reformasi yang dilakukan masyarakat muslim. Ada dua faktor penting yang melatarbelakangi kemunculan madrasah di Indonesia. Pertama, adanya pandangan yang mengatakan bahwa sistem pendidikan Islam tradisional dirasakan kurang bisa memenuhi kebutuhan pragmatis masyarakat. Kedua, adanya kekhawatiran atas kecepatan perkembangan persekolahan Belanda yang akan menimbulkan pemikiran sekuler di masyarakat. Pemerintah kolonial ketika itu sangat khawatir madrasah akan melahirkan generasi penentang kekuasaannya. Tidak heran kalau kebijakan yang dikeluarkan pemerintah kolonial, merupakan bagian dari usahanya untuk mengkooptasi madrasah. Misalnya guru madrasah wajib mempunyai izin dari penguasa, dan di bidang kurikulum, ${ }^{39}$ pelajaran yang diajarkan harus dilaporkan pada penguasa minta persetujuannya. ${ }^{40}$ 
Pada masa era orde lama perkembangan madrasah berlangsung sangat cepat, ${ }^{41}$ sedangkan padaawal pemerintahan ordebaru, pendekatan legal formal yang dijal ankan tidak memberikan dukungan padamadrasah. Tahun 1972 Presiden Suharto mengeluarkan Keppres Nomor 34 Tahun 1972 dan Inpres Nomor 15 Tahun 1974 yang mengatur madrasah di bawah pengelolaan Menteri Pendidikan dan Kebudayaan yang sebelumnya dikelola Kementrian Agama. Tetapi kebijakan tersebut mendapat reaksi keras dari kalangan muslim. Untuk menenangkan reaksi ini, pemerintah kemudian mengeluarkan keputusan bersama antara Mendikbud, Menteri Agama, dan Menteri Dalam N egeri. Isinya mengembalikan statuspengelolaan madrasah di bawah Menteri Agama, tetapi harus memasukkan kurikulum umum yang sudah ditentukam pemerintah. ${ }^{42}$

Meskipun telah keluar SKB tiga menteri tanggal 24 maret 1975 yang memposisikam madrasah dengan sekolah umum, kemudian diperkuat lagi dengan keluarnya UU No. 2 Tahun 1989 Tentang Sistem Pendidikan Nasional yang menegaskan bahwa madrasah adalah sekolah umum yang berciri khas Islam, namun dalam implementasinya pemerintah tetap mengabaikan madrasah. ${ }^{43}$ Tentang pendidikan keagamaan sebagai akibat dualisme sistem pendidikan nasional, hanya disebutkan dalam pasal 11 butir 6 bahwa" pendidikan keagamaan merupakan pendidikan yang mempersiapkan peserta didik untuk dapat menjal ankan peranan yang menuntut penguasaan pengetahuan khusus tentang ajaran agama yang bersangkutan". Pasal 11ayat6inipun diinterpretasikan sebagai pendidikan madrasah yang menerapkan kurikulum nasional. ${ }^{44}$

Dalam UU No. 20 Tahun 2003 Tentang Sistem Pendidikan Nasional, pendidikan agama memperoleh perhatian yang sangat besar. Hal ini dapat dilihat dari:

1. Pada bagian pertimbangan RUU Sisdiknas butir a dikatakan bahwa UUD 1945 mengamanatkan pada pemerintah agar mengusahakan dan menyelenggarakan suatu sistem pendidikan nasional yang meningkatkan keimanan dan ketakwaan kepada Tuhan Yang Maha Esa, serta akhlak yang mulia dalam rangka mencerdaskan kehidupan bangsa yang diatur dengan UU. Dasar pertimbangan ini jelas mengisyaratkan tentang pentingnya pendidikan agama, karena masalah keimanan, ketakwaan dan akhlak mulia merupakan misi utama ajaran agama.

2. Bab II pasal 4 UU Sisdiknas tersebut dinyatakan bahwa pendidikan nasional bertujuan mengembangkan potensi peserta didik agar menjadi manusia yang beriman dan bertakwa pada Tuhan Yang MahaEsa, berakhlak mulia, sehat, berilmu, cakap, kreatif, mandiri, serta menjadi warga negara yang demokratis dan bertanggung jawab dalam rangka mencerdaskan kehidupan bangsa. Untuk menghasilkan orang yang beriman, bertakwa dan berakhlak mulia sebagaimana dimaksud tujuan pendidikan tersebut, jelas harus melalui pendidikan agama.

3. Bab V pasal 13 ayat 1 butir a UU Sisdiknas dinyatakan bahwa setiap peserta didik pada setiap satuan pendidikan berhak mendapatkan pendidikan agama sesuai dengan agama yang dianutnya dan diajarkan oleh pendidik yang seagama. Ketentuan ini selain menegaskan adanya hak bagi setiap peserta didik untuk memperoleh pendidikan agama juga agar agama yang diajarkan pada peserta didik tersebut diberikan oleh guru yang seagama dengannya. 
4. Bab X pasal 37 ayat 3 UU Sisdiknas disebutkan bahwa kurikilum disusun sesuai dengan memperhatikan: a. peningkatan iman dan takwa, b. peningkatanakhlak mulia. Kemudian pada pasal 38dinyatakan pulabahwakurikulum pendidikan dasar dan menengah antara lain wajib memuat pendidikan agama. Selanjutnya pada pasal 39 dikemukakan bahwa kurikulum pendidikan tinggi wajib memuat pendidikan agama. ${ }^{45}$

Pasal-pasal pada UU Sisdiknas di atas selain memperlihatkan dengan jelas tentang pentingnya pendidikan agama juga menginginkan agar pendidikan agama yang diberikan pada setiap jenjang pendidikan bukan pengajaran agama melainkan benarbenar pendidikan agama. Pendidikan agama yang diharapkan oleh UU Sisdiknas tersebut adalah pendidikan agama yang mampu merubah sikap, pola pikir, dan pola tindakan setiap orang yang mempelajari agama. Agama yang dianutnya senantiasa dilibatkan dalam setiap pengambilan kebijakan dan keputusan yang dihadapinya.

Sayangnya berbagai kebijakan pemerintah pasca orde baru yang relatif membawa angin segar bagi pengembangan pendidikan Islam tersebut, agaknya susah diimplementasikan di dunia pendidikan. Hal ini disebabkan masih belum terselesaikannya permasalahan mendasaryang terjadi dalamduniapendidikan nasional, yaitu:

1. Munculnya kesenjangan antara sistem pendidikan Islam dan ajaran Islam. Sistem pendidikan yang ambivelen mencerminkan pandangan dikhotomis yang memisahkan ilmu-ilmu agama Islam dan ikmu-ilmu umum. Pandangan ini jelas bertentangan dengan konsep ajaran Islam sendiri yang bersifat integral; Islam mengajarkan keharusan adanya keseimbangan antara urusan dunia (umum) dengan urusan akhirat (agama)

2. Terjadinya disintegrasi sistem pendidikan Islam. Masing-masing sistem (modern/ umum) Barat dan agama (Islam) tetap bersikukuh mempertahankan kediriannya masing-masing. Meski jalan kompromi semisal modernisasi telah diusahakan sejak beberapa dekade terakhir, tetap karena adanya hegemoni sistem umum atas sistem agama, maka tetap memunculkan dikhotomi sistem dan keilmuan.

3. Munculnya inferioritas pengelola lembaga pendidikan Islam vis a vis pendidikan Barat. Hal ini karena sistem pendidikan Barat telah dijadikan tolak ukur kemajuan dan keberhasilan sistem pendidikan bangsa kita. ${ }^{46}$

Negara secara konstitusional memiliki berbagai kebijakan dan berwenang menerapkannya. Di antara kebijakan itu adalah kebijakan agama, pendidikan, dan politik. Pendidikan agama sebagai subsistem kebijakan pendidikan ${ }^{47}$ berada di tengah di antara kebijakan negara dan politik. Maksudnya pendidikan agama memerankan dirinya sebagai pelayan agama dengan memanfaatkanteori-teori pendidikandandemi eksistensinya di suatu negara memerlukan dukungan kebijakan agama, pendidikan, dan politik. Secara faktual rumusan arah kebijakan agama di tengah kebijakan pendidikan dan politik dimaksudkan telah tertuang dalam GBHN tahun 1999-2004. ${ }^{48}$

Pada kebijakan tersebut ditegaskan tentang posisi sentral agama dalam

fungsi, peran, dan kedudukannya sebagai landasan moral, spiritual, dan etika dalam 
penyelenggaraan negara. Segala aturan perundang-undangan juga diupayakan agar tidak bertentengan dengan moralitas agamaagama. Supaya fungsi ini dapat teraktualisasi secara optimal, kebijakan negara diarahkan pada peningkatan kualitas pendidikan agama melalui penyempurnaan sistem pendidikan agama. Tujuannya agar pendidikan agama lebih terpadu dan integral dengan sistem pendidikan nasional. ${ }^{49}$

Upaya pembaruan diarahkan kepada sistem pendidikan, termasuk pembaruan kurikulum, pemberdayaan sekolah sebagai pusat pembudayaan nilai, sikap dan kemampuan, serta pembaruan dan pemantapan sistem pendidikan nasional berdasarkan prinsip desentralisasi, otonomi keilmuan, dan manajemen. Pembaruan dimaksud didukung dengan kebijakan politik yang diarahkan untuk meningkatkan peran DPR/ MPR dan lembaga tinggi negara lainnya dengan menegakkan fungsi dan tanggung jawab yang mengacu pada prinsip pembagian kekuasaan dan tata hubungan yang jelas antara lembaga eksekutif, legeslatif, dan yudikatif. Untuk lebih jelasnya dapat dilihat pada bagan berikut ini:
Bertolak dari hal di atas dapat dipahami bahwa kebijakan agama diperlukan oleh pendidikan agama sebagai penegak eksistensi dogmatik. Kebijakan pendidikan dibutuhkan sebagai penegak eksistensi struktural. Adapun kebijakan politik diperlukan sebagai peletak dan penegak dasar yuridis. ${ }^{50}$

Oleh karenaitu pendidikan harusberperan sebagai sarana pemberdayaan (empowerment) harus secara sadar menyiapkan peserta didik dalam kehidupan masyarakat baik sebagai individu maupun sebagai anggota masyarakat. Dengan kata lain, pendidikan berfungsi sebagai sarana pemberdayaan individu dan masyarakat guna menghadapi masa depan. Pemberdayaan hanya mempunyai makna jika proses pemberdayaan menjadi bagian dan fungsi dari kebudayaan. Pendidikan Islam yang berdaya dan memberdayakan akan terwujud apabila:

a. Memiliki visi, misi, dan orientasi strategis ke depan yang jelas.

b. Memiliki legitimasi sosial, intelektual dan moral yang kuat.

c. Berbasis pada masyarakat dan meresponi tuntutan zaman.

Gambar 1. Hubungan Pendidikan Agama dengan Sitem Pendidikan Nasional

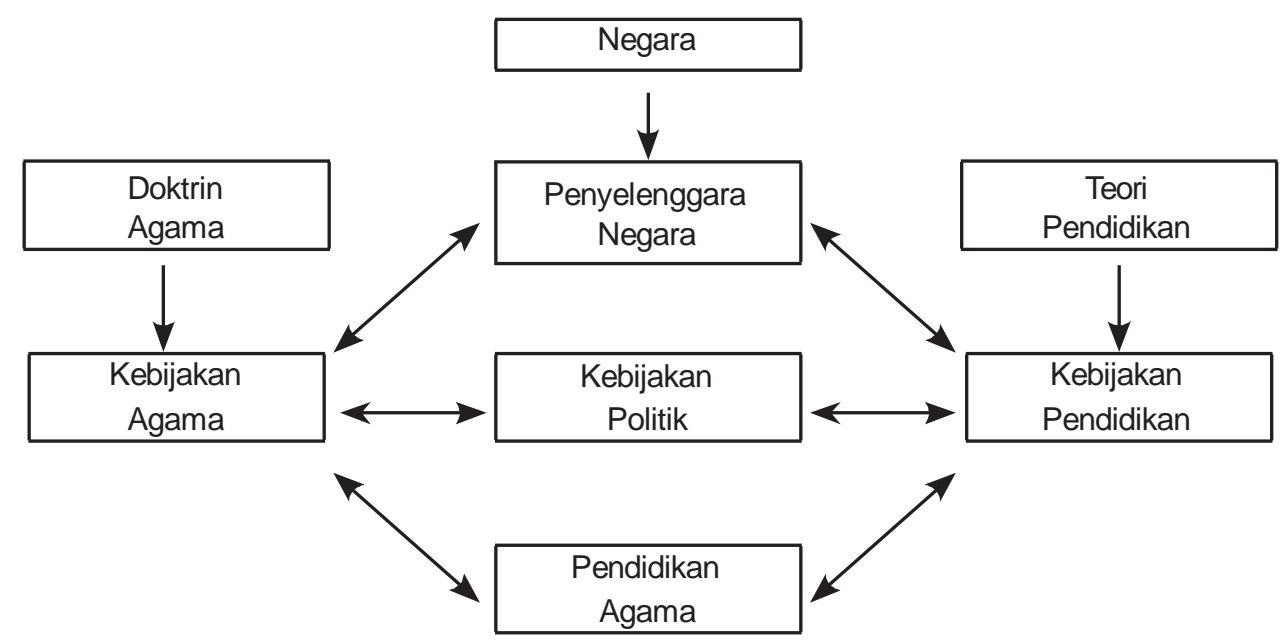


d. Dikelola dengan manajemen modern yang profesional, rasional, terbuka, akuntabel, humanis, memiliki akses, kerjasama dan kemitraan global ${ }^{51}$

\section{Kesi mpulan}

Reformasi pendidikan pada dasarnya memiliki tujuan agar pendidikan dapat berjalan lebih efektif dan efesien mencapai tujuan pendidikan nasional. Di dalam berbagai Undang-undang dan Peraturanterlihatdengan jelas adanya kemauan politik yang kuat dari pemerintah Indonesia untuk memberdayakan rakyat Indonesia melalui pemberian pendidikan yang unggul dan memberdayakan dengan meninjau kembali seluruh komponen yang terkait dengan pendidikan. Pemerintah dengan jelas telah meletakkan standar isi, proses, kompetensi lulusan, pendidik dan tenaga kependidikan, sarana dan prasarana, pengelolaan, pembiayaan, dan penilaian pendidikan.

Selama kurun waktu Iebih dari lima dasawarsa sejak Indonesia bebas dari kolonialisme, pendidikan Islam bisa dikatakan belum bisa memberikan kontribusi apa-apa terhadap kemajuan bangsa, di samping tidak mampu berkutik ketika dituntut perannya dalam mengatasi berbagai persoalan moral dan mentalitas bangsa ini. Pendidikan Islam baik pesantren maupun madrasah tanpa disadari masih terjebak pada orientasi dikotomik. Indikasinya, dalam lembaga-lembaga pendidikan Islam tersebut transformasi pengetahuan dan nilai-nilai agama terasa begitu kuat sehingga hampirhampir melupakan realitas kebutuhan pasar kerja.

Segala aturan perundang-undangan Pendidikan dalam konteks keindonesiaan diupayakan agar tidak bertentangan dengan moralitas agama-agama. Supaya fungsi ini dapat teraktualisasi secara optimal, kebijakan negara diarahkan pada peningkatan kualitas pendidikan agama melalui penyempurnaan sistem pendidikan agama. Tujuannya agar pendidikan agama lebih terpadu dan integral dengan sistem pendidikan nasional. Upaya pembaruan diarahkan kepada sistem pendidikan, termasuk pembaruan kurikulum, pemberdayaan sekolah sebagai pusat pembudayaan nilai, sikap dan kemampuan, serta pembaruan dan pemantapan sistem pendidikan nasional berdasarkan prinsip desentralisasi, otonomi keilmuan, dan manajemen.

\section{Wallahu A'lam Bissawab}

\section{Endnotes:}

1 Proopert Lodgesebagaimana yang dikutip oleh Suyanto pernah mengatakan life is education, and education is life. Pernyataan lodge ini mengisyaratkan bahwa antara pendidikan dengan kehidupan hampir-hampir tidak bisa dibedakan sama sekali. Kedua pengertian (pendidikan dan kehidupan) telah menyatu dalam sebuah kerangka filosofis, bahwa proses dalam pendidikan tidak lain adalah proses bagi manusia dalam mengarungi samudra kehidupan, begitu juga sebaliknya. Makna filosofis pemdidikan adalah proses bagaimana manusia dalam mengenali diri dengan segenap potensi yang dimilikinya dan memahami apa yang tengah dihadapinya dalam realitas kehidupan yang nyata ini. Inilah problem fundamental dari filosofi pendidikan yang kurang banyak dipahami oleh para pakar dan praktisi pendidikan kita saat ini. Lihat Suyanto, Dinamika Pendidikan Nasional (Dalam Percaturan Dunia Global), (Jakarta:PSAP Muhammadiyah, 2006), h. ix

2 Suwito, Pendidikan yang memberdayakan, Pidato Pengukuhan Guru Besar Sejarah dan Pemikiran Pendidikan Islam IAIN Syarif Hidayatullah Jakarta Tanggal 3Januari 2002, h. 1 
3 Krisis yang dialami bangsa Indonesia baik ekonomi, politik, dan keamanan belum juga dapat diatasi. Berbagai krisis ini berdampak negative terhadap dunia pendidikan dengan memunculkan keseimbangan baru pendidikan. Pada keseimbangan baru ini, pelayananan pendidikan tidak dapat dilaksanakan dengan menggunakan cara seperti biasa (bussines as usual). Orientasi pelayanan pendidikan dengan menggunakan cara berfikir lama tidak dapat diterapkan begitu saja dan bahkan mungkin tidak dapat digunakan untuk mengatasi masalah pada keseimbangan baru ini. Cara cara berfikir baru dan terobosan-terobosan baru harus diperkenalkan dan diciptakan untuk mengatasi permasalahan pendidikan pada saat ini dan di masa mendatang. Dengan kata lain reformasi pendidikan merupakan suatu imperative action. Zamrozi, Paradigma Pendidikan di Masa Depan, (Yogyakarta: Bayu Indra Grafika, 2000), h. 158

4 Indra djati Sidi, Menuju Masyarakat Belajar Menggagas Paradigma Baru Pendidikan, Jakarta: Paramadina, 2001), h. 14.

5 Komaruddin Hidayat, Memetakan Kembali Struktur Keilmuan Islam kata pengantar dalam Fuaduddin dan Cik Hasan Bisri, Dinamika Pemikiran Islam di Perguruan Tinggi: Wacana Tentang Pendidikan Agama Islam, (Jakarta: Logos, 2002), h. xi

6 Komaruddin Hidayat, Memetakan Kembali Struktur Keilmuan Islam kata pengantar dalam Fuaduddin dan Cik Hasan Bisri, Dinamika Pemikiran Islam di Perguruan Tinggi: Wacana Tentang Pendidikan Agama Islam, h, xii-xiv. Hal yang sama juga dikemukakan oleh Abuddin Nata bahwa pendidikan pada umumnya, termasuk pendidikan Islam saat ini cendrung berhasil membina kecerdasan intelektual, dan keterampilan, dan kurang berhasil menumbuhkan kecerdasan emosional. Hal ini terjadi karena beberapa sebab, di antaranya adalah pertama, pendidikan yang diselenggarakan saat ini cendrung hanya pengajaran, dan bukan pendidikan. Kedua, pendidikan saat ini sudah berubah dari orientasi nilai dan idealisme yang berjangka panjang kepada yang bersifat materialisme, individualisme, dan mementingkan tujuan jangka pendek. Ketiga, metode pendidikan yang diterapkan tidak bertolak dari pandangan yang melihat manusia sebagai makhluk yang paling mulia dan memiliki potensi yang bukan hanya potensi intelektual, tetapi juga potensi emosional. Keempat, pendidikan Islam kurang mengarahkan siswanya untuk mampu merespon berbagai masalah actual yang muncul di masyarakat, sehingga terjadi kesenjangan antara dunia pendidikan dengan dunia kehidupan di masyarakat. A buddin Nata, Manajemen Pendidikan Mengatasi Kelemahan Pendidikan Islam di Indonesia, h. 53-54

7 Terdapat dua pendekatan yang menonjol dalam mempelajari Islam, pertama, mempelajari Islam untuk kepentingan mengetahui bagaimana cara beragama yang benar. Di sini aspek religiusitas dan spirilualitas menjadi sangat penting sehingga esensi ajaran agama bisa menginternalisasi ke dalam diri pribadipribadi dalam aktivitas kesehariannya. Kedua, mempelajari Islamsebagai sebuah pengetahuan. Pendekatan kedua ini berkembang sangat pesat di Barat. Para peneliti dan pemikir yang memandang bahwa Islam hanya sebagai pengetahuan adalah memang sangat terpisah dengan ajaran yang dikuasainya. Dalam orientasi pendidikan, kedua pendekatan mempelajari Islam ini tampaknya perlu terus mendapatperhatian yang serius. Sehinggatidak saja terjadi peningkatan pengamalan religiusitas di kalangan para penganut Islam, melainkan juga terjadi peningkatan keilmuan Islam yang luar biasa. Dua pendekatan ini karenanya mesti menjadi orientasi pendidikan agama. A buddin Nata, Manajemen Pendidikan Mengatasi Kelemahan Pendidikan Islam di Indonesia, h. xiv-xv

8 A. Malik Fadjar, Reorientasi Pendidikan Islam, (Jakarta: Fajar Dunia, 1999), h. 31

9 A. Malik Fadjar, Reorientasi Pendidikan Islam, h. 31

10 A hmad D. Marimba, PengantarFilsafat Pendidikan Islam, (Bandung: PT. al-Ma'arif, 1981), h.. 3

11 M. Natsir Ali, Dasar-Dasar Ilmu Mendidik, (Jakarta: Mutiara, 1997), h. 23 
12 Syekh Ali Mahfuz, Hidayat al-Musyidin (Cet. VI; Kairo: al-Matba'at al-Usmaniyyah al-Misiyyah, 1958), h. 69-70.

13 Sayyid Muhammad Nuh, Manhaj ahl al Sunnah Waal Jama'ah Fi Qadiyyat al-Taqayyur Bi Janibaih al-Tarbawi Wa al-Da'awiy (Cet. II;t.tp: Dar alWafa al-Tiba'ah wa al-Nasyr, 1991), h. 29.

14 Abu Khalil Abu al-Ainain, Falsafah al-Tarbiyah al-Islamiyah fi al-Qur'an al-Karim, (T.t: Dar al-Fikr al-A rabi, 1980), h. 154

15 Ini sama dengan tujuan pendidikan yang dirumuskan oleh al-Ghazali dalam M uhammad Athiyah al-Abrasyi, Al-Tarbiyah al-Islamiyah, (T.t: t.pn, t.th), h. 9.Ibn Khaldun sebagaimana yang dikutip oleh Athiyah merumuskan dua tujuan pendidikan, 1). Tujuan yang berorientasi akhirat yaitu membentuk hamba-hamba Allah yang dapatmelaksanakan kewajibannyakepada Allah. 2). Tujuan yang berorientasi dunia yaitu membentuk manusia-manusia yang mampu menghadapi segala bentuk kehidupan yang lebih layak dan bermanfat bagi orang lain. Lihat M. Athiyah al-A brasyi, Al-Tarbiyah al-Islamiyah wa Falsafatuha, (Mesir: Isa al-Babi al-Halabi, 1975), h. 277. Lihat juga Majid 'A rsan al-Kailani, Al-Fikri al-Tarbawi inda Ibn Taimiyah, (Madinah al-M unawwarah, Maktabah Dar al-Turas, T.th), h. $107-115$

16 Syed Muhammad Naquib al Attas, Konsep Pendidikan Dalam Islam, (Bandung: Mizan, 1984), h. 60

17 Syed Muhammad Naquib al Attas, Konsep Pendidikan Dalam Islam, h. 59

18 Ki Hajar Dewantara, Bagian Pertama Pendidikan, (Yogyakarta: Majlis Luhur Persatuan Taman Siswa, 1962), h. 19

19 A budin Nata, Filsafat Pendidikan Islam, (Jakarta: Logos Wacana Ilmu, 2001), h. 9-10

20 H.M Muzayyin Arifin, Filsafat Pendidikan Islam, (Jakarta: PT Bina Aksara, 1987), h. 13. Dalam struktur sosial kebudayaan, pendidikan Islam paling tidak mengandung empat unsur yang kemudian dijadikan sebagai dustur kebudayaan suatu bangsa, yaitu: 1. Unsur etika (moral) untuk membentuk ikatan-ikatan sosial, 2. Unsur estetika untuk membentuk cita rasa umum,
3. Logika terapan untukmenentukan bentukbentuk aktivitas umum, 4. Tekhnologi terapan yang sesuai dengan semua jenis yang ada dalam ragam masyarakat atau industri.Lihat Malik bin Nabi, Membangun Dunia Baru Islam, Penerjemah Afif Muhammad dan Abdul Adhiem, (Bandung:Mizan, 1995), h. 103. Merujuk pada batasan ini maka praktek praktek pendidikan Islam merupakan penjabaran keempat unsur tersebut. Pendidikan Islam seyogyanya menjadi sarana pembentukan situasi berpengetahuan dan berakhlak mulia. Prosesnya bukan berupa rangkaian indoktrinasi pengetahuan dan mencampakkan keempat unsur-unsur pendidikan itu dalam bingkai yang terpilahpilah. Proses pendidikan yang dilakukan seyogyanya merupakan proses pemberian sejumlah informasi mengenai pengalaman untuk memperoleh ilmu pengetahuan. Di sini peserta didik diarahkan untuk menemukan bentuk pengetahuan yang diinginkan, sesuai dengan kebutuhan masa depannya yang pasti berbeda dengan lingkungan dan persoalan yang dialami seorang pendidik. Bagi Abduh pendidikan yang baik adalah pendidikan yang dalam prosesnya mampu mengembangkan seluruh fitrah peserta didik, terutama fitrah akal dan agamanya. Lihat Muhammad A bduh, "AlMadaris al-Tajhiziyat wa al-Madaris al-Aliyat", dalam 'Imarah (ed), Al-A'mal al-Kamil li al-Imam Muhammad Abduh, (Bairut: al-Muassasah alA rabiyah li al-Dirasah wa al-Nashar, 1972), Juz III, h. 117

21 Reformasi pendidikan adalah proses yang kompleks, berwajah majemuk dan memiliki jalinan tali temali yang amat interaktif, sehingga reformasi pendidikan memerlukan pengerahan segenap potensi yang ada dan dalam tempo yang panjang. Betapa kompleknya reformasi pendidikan dapat dipahami karena tempo yang diperlukan amat panjang, jauh lebih panjang apabila dibandingkan tempo yang diperlukan untuk melakukan reformasi ekonomi, apalagi dibandingkan tempo yang diperlukan untuk reformasi politik. Seminar reformasi di Jerman Timur yang diselenggarakan sehabis tembok Berlin diruntuhkan mencatat bahwa 
untuk reformasi politik diperlukan waktu cukup enam bulan, untuk reformasi ekonomi diperlukan waktu enam tahun, dan untuk reformasi pendidikan diperlukan waktu enam puluh tahun. Sungguhpun demikian, hasil dan produk setiap fase atau periode tertentu dari reformasi pendidikan harus dapat dipertanggungjawabkan. Di samping itu yang lebih penting adalah reformasi pendidikan harus memberikan peluang bagi siapapun yang aktif dalam pendidikan untuk mengembangkan langkah-langkah baru yang memungkinkan peningkatan mutu pendidikan. Lihat Zamrozi, Paradigma Pendidikan di Masa Depan, h. 159

22 Yusufhadi Miarso, “Perubahan Paradigma Pendidikan Peran Tekhnologi Pendidikan Dalam Penyampaian Misi dan Informasi Pendidikan" dalam Menyemai Benih Tekhnologi Pendidikan, (Jakarta: Kencana, 2005), h. 694

23 Sistem pendidikan nasional kita yang berlaku sekarang pada dasarnya bertujuan untuk membudayakan peserta didik/ warga belakar.

Kebijakan ditentukan sangat sentralistis (etatisme), sehingga tidak memberi peluang bagi wilayah apalagi sekolah dan guru untuk mengembangkan prakarsa yang sesauai dengan karakteristik peserta didik dan kondisi lingkungan. Pada hakikatnya peserta didik diindoktrinasi untuk menelan pelajaran yang diberikan. Gurupun "diprogram" untuk melaksanakan kegiatan pembelajarannya secara baku sesuai dengan pedoman tertentu. Kenyataan ini pada dasarnya mengingkari hak seseorang, atau kurang memanusiakan peserta didik/ warga belajar. Lihat Yusufhadi Miarso, "Perubahan Paradigma Pendidikan Peran Tekhnologi Pendidikan Dalam Penyampaian Misi dan Informasi Pendidikan" dalam Menyemai Benih Tekhnologi Pendidikan, h. 694

24 Belajar berbasis aneka sumber (BEBAS) adalah satu paradigma baru pada lapis pengalaman belajar. Reformasi paradigma dengan BEBAS memberikan kesempatan kepada setiap peserta didik untuk memilih dan menentukan sendiri sumber yang digunakan untuk belajar. Tugas utama guru adalah sesuai dengan moto Depdiknas "tut wuri handayani, hing ngarso sung tulada, hing madya mangun karsa". Menumbuhkembangkan sikap (termasuk sikap ilmiah) dan membangkitkan motivasi belajar merupakan tugas utama setiap tenaga kependidikan. Di dalam kelas, guru merupakan pengelola kegiatan belajar yang lebih banyak berupa memberikan bantuan dalam pemilihan dan penggunaan sumber belajar. Peserta didik lebih banyak dituntut untuk mampu belajar mandiri serta belajar secara kooperatif dengan teman dan orang lain dalam lingkungannya. Pengelolaan berbasis sekolah pada dasarnya adalah perubahan pada lapis kedua (sistem pembelajaran) dan merupakan konsekwensi langsung dari perubahan paradigma pengalaman belajar pada lapis pertama. Paradigma baru ini sesuai dengan Tap MPR 1999 tentang Pemerintah Daerah. Dengan adanya Undang-undang No. 22 dan 25 tahun 1999 tentang Pemerintah Daerah dan Perimbangan Keuangan antara Pemerintah Pusat dan Daerah, sebagian wewenang telah diberikan kepada daerah propinsi dan kabupaten/ kodya secara luas, termasuk dalam pendidikan. Arti pengelolaan berbasis sekolah adalah pelimpahan wewenang pada lapis sekolah untuk mengambil keputusan mengenai alokasi dan pemanfaatan sumbersumber berdasarkan aturan akuntabilitas yang berkaitan dengan sumber tersebut. Meskipun sekolah diberikan otonomi dalam menyelanggarakan pendidikan, namun sekolah tidak dapat berbuat semaunya sendiri. Ada beberapa rambu-rambu konseptual maupun legal yang harus diikuti. Salah satu ramburambu konseptual tersebut adalah visi, misi, dan tujuan pendidikan yang ditetapkan oleh pemerintah daerah bersama DPRD. Sedangkan pola pendidikan alternatif sebenarnya bukan merupakan hal yang baru sama sekali. Pengertian pendidikan alternatif adalah meliputi sejumlah besar cara pemberdayaan peserta didik yang dilakukan berbeda dengan cara konvensional. Berbagai bidang pendidikan alternatif adalah; 1. Pendidikan di rumah (home schooling) yang diselenggarakan oleh orang tual keluarga, 2. Pendidikan di tempat ibadah 
termasuk pendidikan pesantren. 3. Pendidikan anak yang bermasalah, 4. Pendidikan berbasis masyarakat, 5. Pendidikan terbuka seperti SLTP Terbuka. Lihat Yusufhadi Miarso, “Perubahan Paradigma Pendidikan Peran Tekhnologi Pendidikan Dalam Penyampaian Misi dan Informasi Pendidikan" dalam Menyemai Benih Tekhnologi Pendidikan, h. 696-698

25 Abudin Nata, Modernisasi Pendidikan Islam di Indonesia, (Jakarta:UIN Jakarta Press, 2002), h. 5

26 Suyanto dan Jihad Hisyam, Refleksi dan reformasi Pendidikan di Indonesia Memasuki Millenium III, (Yogyakarta: Adi Cita Karya Nusa, 2000), h. 2

27 Secara umum pendidikan nasional sedang menghadapi tantangan yang berat, yaitu tantangan internal dan eksternal. Secara internal kita telah dihadapkan pada hasil-hasil studi internasional yang selalu menempatkan kita pada posisi juru kunci untuk pendidikan dan ranking atas untuk korupsi. Sebagai contoh misalnya hasil studi PERC (the Political and Economic Risk Consultancy) tahun 2004 tentang Corruption Country, menempatkan Indonesia padaranking pertama seAsia. Sedangkan dalam hal pembangunan manusia yang indikatornya meliputi pendidikan, kependudukan, dan kesehatan, UNDP dalam laporannya, Human Development Report 2004 hanya menempatkan Indonesia di peringkat 111 dari 177 negara. Adi sisi lain kita juga di hadapkan dengan tantangan eksternal yaitu perubahan yang cepat dari lingkungan strategis di luar negara kita. Pasar bebas ASEAN (AFTA) berlaku sejak tahun 2003 yang lalu. Beberapa tahun ke depan, kerjasama ekonomi AsiaPasifik (APEC) akan berlaku mulai 2010 untuk negara-negara maju dan 2020 untuk seluruh anggotanya termasuk Indonesia. Kita berada dalam posisi untuk tidak bisa mengelak dari tekanan eksternal tersebut. Menghadapi kedua tantangan ini, maka perubahan dan inovasi merupakan kata kunci yang perlu dijadikan dalam mengembangkan pendidikan nasional. Pengembangan itu tidak dapat dilakukan sendiri oleh pemerintah pusat atau daerah, tetapi memerlukan masukan-masukan dan gerakan bersama antarsemua institusi, baik institusi pendidikan, institusi ekonomi, politik, sosial, budaya, agama, sertamasyarakat pada umumnya, untuk mendukung cita-cita tersebut. Lihat Muhaimin, Nuansa Baru Pendidikan Islam Mengurai Benang Kusut Dunia Pendidikan, (Jakarta: PT RajaGrafindo Persada, 2006), h. 71 dan 73

28 Zamrozi, Paradigma Pendidikan di Masa Depan, h. 160

29 Suyanto, Dinamika Pendidikan Nasional (Dalam Percaturan Dunia Global), h. 7

30 Michael Porter, "Creating Tomorrow's Advantages" in Rowan Gibson (ed), Rethinking the Future, (London: Nicholas Brealey Publishing Limited, 1997), h. 54

31 Suyanto, Dinamika Pendidikan Nasional (Dalam Percaturan Dunia Global), h. 7. Kesatuan visi dari sekolah, peserta didik, masyarakat dan keluarga menjadi sangat penting bagi proses pencapaian tujuan belajar yang memiliki makna bagi peserta didikitu sendiri. Lihat R.C. Wallace Jr, The Learning School: A Guide to Vision-Based Leadership, (California: Corwin Press, 1997), h. 4

32 Abudin Nata, Modernisasi Pendidikan Islam di Indonesia, 7-8

33 Abudin Nata, Modernisasi Pendidikan Islam di Indonesia, 8

34 Azyumardi Azrah,Paradigma Baru Pendidikan Nasional: Rekonstruksi dan Demokratisasi (Jakarta, Penerbit Buku Kompas, 2002)

35 Armai Arief, Reformulasi Pendidikan Islam, (Jakarta: CRSD Press, 2005), h. 25

36 A. Malik Fadjar, Reorientasi Pendidikan Islam, (Jakarta: Fajar Dunia: 1999), h. 79.

37 Syed Abdul Wahid, Thought and Reflektions of Iqbal, (Lahore:Muhammad A shraf. 1964), h.60

38 M uhammad Iqbal, The Reconstruction of Religions Thought in Islam, (New Delhi: Kitab Bhavan, 1981), h.156

39 Menurut Beane konsep kurikulum dapat diklasifikasikan kedalamempatjenispengertian yang meliputi kurikulum sebagai produk, kurikulum sebagai program, kurikulum sebagai hasil belajar yang diinginkan, dan kurikulum sebagai pengalaman belajar bagi peserta didik. Lihat J.A Beane, Toepfer, C.F. 
Allesi, S.J Curriculum Planing and Development, (Boston::Allyn and Bacon, Inc, 1986), h. 29

40Armai Arief, Reformulasi Pendidikan Islam, h. 6061

41 Pada pertengahan tahun 1960-an, terdapat 13.057 Madrasah Ibtidaiyah (MI), pendidikan setingkat sekolah dasar (SD) pada sistem pendidikan umum. Pada pendidikan tingkat lanjutan pertama atau Madrasah Tsanawiyah (MTs) terdapat 776 madrasah dengan 87.932 siswa. Sedangkan di tingkat berikutnya atau Madrasah Aliyah terdapat 16 madrasah dengan 1.881 siswa. Jumlah peserta pendidikan ini merupakan angka yang luar biasa bagi sejarah pendidikan di Indonesia. Lihat Armai Arief, Reformulasi Pendidikan Islam, h. 60-61

42 Armai Arief, Reformulasi Pendidikan Islam, h. 62

43 Husni Rahim, “Madrasah Menggugat, Madrasah Digugat, dalam Jamaluddin (ed), Mendiskusikan Kembali Eksistensi Madrasah, (Jakarta: Logos, 2003), xiv

44 Armai Arief, Reformulasi Pendidikan Islam, h. 5960

45 Abudin Nata, Modernisasi Pendidikan Islam di Indonesia, h. 58-60

46 Azyumardi Azra, kata pengantar dalam Armai Arief, Reformulasi Pendidikan Islam, h. xiii-xiv. Yang terjadi sekarang adalah, bahwa umat manusia kehilangan dinamika, kreativitas dan progresivitas. Kajian yang kritis dan mendalam terhadap pemikiran-pemikiran keslaman tidak dapat berkembang secara alami. Hal ini terjadi, karena adanya sikap penolakan terhadap pemikiran manusia yang kreatif karena adanya pemahaman yang dikotomik, antara ilmu-ilmu sekuler di sutu pihak dan ilmu-ilmu agama dipihak lain. Lihat Fazlur Rahman, Islam and Modernitas, Transformation of an IntelectualTradition, (Chicago: The University of Chicago Press, 1982), h.48

47 Posisi ini secara eksplisit dituangkan dalam Bab X pasal 36-37 UU Sisdiknas No. 20 tahun 2003. Pasal 36 ayat 3 butir a dan b menyatakan kurikulum disusun sesuai dengan jenjang pendidikan dalam kerangka kesatuan Negara
Republik Indonesia dengan memperhatikan: a.

Peningkatan Iman dan takwa, b. peningkatan akhlak mulia. Pasal 37 ayat 1 butir a dan ayat 2 butir a menyatakan: bahwa kurikulum pendidikan dasar, menengah dan pendidikan tinggi wajib memuat pendidikan agama. Lihat Direktorat Pendidikan Dasar dan Menengah Bagian Proyek Penilaian Hasil Belajar Tahap Akhir nasional Jakarta Tahun 2003, UndangUndang Republik Indonesia Nomor 20 Tahun 2003 tentang Sistem Pendidikan Nasional, h. 16-17

48 Lihat perubahan UUD 1945 dan Ketetapanketetapan SU-M PR Tahun 1999, (J akarta: Rineka Cipta, 1999), h. 90-95

49 M. Saerozi, “Bila Negara Mengatur Agama: Konfesionalitas Kebijakan Pendidikan

Nasional" dalam Ulumuna Vol.VII Edisi 12 No. 2 Juli-Desember 2003, h. 267

50 M. Saerozi, "Bila Negara Mengatur Agama: Konfesionalitas Kebijakan Pendidikan Nasional" dalam Ulumuna Vol.VII Edisi 12 No. 2 Juli-Desember 2003, h. 267-268

51 Suwito, Pendidikan yang memberdayakan, Pidato Pengukuhan Guru Besar Sejarah dan Pemikiran Pendidikan Islam IAIN Syarif Hidayatullah Jakarta Tanggal 3Januari 2002, h. 28

\section{DAFTAR PUSTAKA}

Abduh, Muhammad “Al-Madaris al-

Tajhiziyat wa al-Madarisal-A liyat", dalam 'Imarah (ed), Al-A'mal al-Kamil li al-Imam Muhammad Abduh, Bairut: al-Muassasah al-Arabiyah li al-Dirasah wa al-Nashar, 1972, Juz III.

Al-Abrasyi, M. Athiyah,,Al-Tarbiyah alIslamiyah wa Falsafatuha, Mesir: Isa al-Babi al-halabi, 1975

------, M. Athiyah, Al-Tarbiyah al-Islamiyah, T.t: t.pn, t.th

Al-Ainain, Abu Khalil A bu, Falsafah al-Tarbiyah al-Islamiyah fi al-Qur'an al-Karim, T.t: Dar al-Fikr al-Arabi, 1980 
Ali, M. Natsir, Dasar-Dasar Ilmu Mendidik, Jakarta: Mutiara, 1997

Arief, Armai, Reformulasi Pendidikan Islam, Jakarta: CRSD Press, 2005

Arifin, Muzayyin, Filsafat Pendidikan Islam, Jakarta: PT Bina Aksara, 1987

Al-Attas, Syed Muhammad Naquib, Konsep Pendidikan Dalam Islam, Bandung: Mizan, 1984

Ashraf, New Horizon in Muslim Education, (London:ThelslamicA cademy, Cambridge University, 1985

Azra, Azyumardi, Paradigma Baru Pendidikan Nasional: Rekonstruksi dan Demokratisasi, Jakarta, Penerbit Buku Kompas, 2002

Beane, J.A, Toepfer, C.F. Allesi, S.J Curriculum Planing and Development, Boston:Allyn and Bacon, Inc, 1986

Bocock, Jean dan David Watson (ed), Managing University Curriculum Making Common Cause, Buckingham:SRHE and Open University Press, 1994

Bruner, Jerome S, The Relevance of Education, (New York: W.W. Norton \& Company. Inc, 1973

Daud, Wan Mohd Nor Wan, The Concept of Knowledge in Islam and Its Implications for Education in a Developing Country, New York:Mansell, 2002

Dewantara, Ki Hajar, Bagian Pertama Pendidikan, Yogyakarta: Majlis Luhur Persatuan Taman Siswa, 1962

Direktorat Pendidikan Dasar dan Menengah Bagian Proyek Penilaian Hasil Belajar Tahap Akhir nasional Jakarta Tahun 2003, Undang-Undang Republik Indonesia Nomor 20 Tahun 2003 tentang Sistem Pendidikan Nasional
Fadjar,A. Malik, Reorientasi Pendidikan Islam, Jakarta: Fajar Dunia: 1999

Hidayat, Komaruddin, Memetakan Kembali Struktur Keilmuan Islam kata pengantar dalam Fuaduddin dan Cik Hasan Bisri, Dinamika Pemikiran Islam di Perguruan Tinggi: Wacana Tentang Pendidikan Agama Islam, Jakarta: Logos, 2002

Iqbal, Muhammad, The Reconstruction of Religions Thought in Islam, New Delhi: Kitab Bhavan, 1981

Al-Kailani, Majid 'Arsan, Al-Fikri alTarbawi inda Ibn Taimiyah, Madinah alMunawwarah, Maktabah Dar al-Turas, T.th

Kerr, Clark, The Uses of The University, New York: Harper \& Row, 1966

Perubahan UUD 1945 dan Ketetapanketetapan SU-MPR Tahun 1999, Jakarta: Rineka Cipta, 1999

M. Saerozi, “Bila Negara Mengatur Agama: Konfesionalitas Kebijakan Pendidikan Nasional" dalam Ulumuna Vol.VII Edisi 12 No. 2 Juli-Desember 2003

Mahfuz,Syekh Ali, Hidayat al-Musyidin; Kairo: al-Matba'at al-Usmaniyyah al-Misiyyah, 1958

Marimba, Ahmad D. Marimba, Pengantar Filsafat Pendidikan Islam, Bandung: PT. alMa'arif, 1981

Miarso,Yusufhadi, “Perubahan Paradigma Pendidikan Peran Tekhnologi Pendidikan Dalam Penyampaian Misi dan Informasi Pendidikan" dalam Menyemai Benih Tekhnologi Pendidikan, Jakarta: Kencana, 2005 
Muhaimin, Nuansa Baru Pendidikan Islam Mengurai Benang Kusut Dunia Pendidikan, Jakarta: PT RajaGrafindo Persada, 2006

McNeil, John, Curriculum A Comprehensive Introduction, Boston: Little, Brown and Company (Inc), 1977

Nabi, Malik bin, Membangun Dunia Baru Islam, Penerjemah Afif Muhammad dan Abdul Adhiem, Bandung:Mizan, 1995

Nata, A budin, Filsafat Pendidikan Islam, Jakarta: Logos Wacana IImu, 2001

-------, Abudin, Modernisasi Pendidikan Islam di Indonesia, Jakarta:UIN Jakarta Press, 2002

Nuh, Sayyid Muhammad, Manhaj ahl al Sunnah Waal Jama'ah Fi Qadiyyat al-Taqayyur Bi Janibaih al-Tarbawi Wa al-Da'awiy, t.tp: Dar al-Wafa al-Tiba'ah wa al-Nasyr, 1991

Porter, Michael "Creating Tomorrow's Advantages" in Rowan Gibson (ed), Rethinking the Future, London: Nicholas Brealey Publishing Limited, 1997

Rahim, Husni "Madrasah Menggugat, Madrasah Digugat, dalam Jamaluddin (ed), Mendiskusikan Kembali Eksistensi Madrasah, Jakarta: Logos, 2003

Rahman,Fazlur,Islam and Modernitas, Transformation of an Intelectual Tradition, Chicago: The University of Chicago Press, 1982
Sidi, Indra djati, Menuju Masyarakat Belajar Menggagas Paradigma Baru Pendidikan, Jakarta: Paramadina, 2001

Suwito, Pendidikan yang memberdayakan, Pidato Pengukuhan Guru Besar Sejarah dan Pemikiran Pendidikan Islam IAIN Syarif Hidayatullah Jakarta Tanggal 3 Januari 2002

Suyanto, Dinamika Pendidikan Nasional (Dalam Percaturan Dunia Global), Jakarta:PSAP Muhammadiyah, 2006

------dan Jihad Hisyam, Refleksi dan reformasi Pendidikan di Indonesia Memasuki Millenium III, Yogyakarta: Adi Cita Karya N usa, 2000

Tibi, Bassam, Islam and The Cultural Accomodation of Social Change, Penerjemah ClareKrojzl, Oxford: Westview Press, 1990

Zamrozi, Paradigma Pendidikan di Masa Depan, Yogyakarta: Bayu Indra Grafika, 2000

Wahid, Syed Abdul,Thought and Reflektions of Iqbal, Lahore:Muhammad Ashraf. 1964

Wallace Jr, R.C. The Learning School: A Guide to Vision-Based Leadership, California: Corwin Press, 1997 